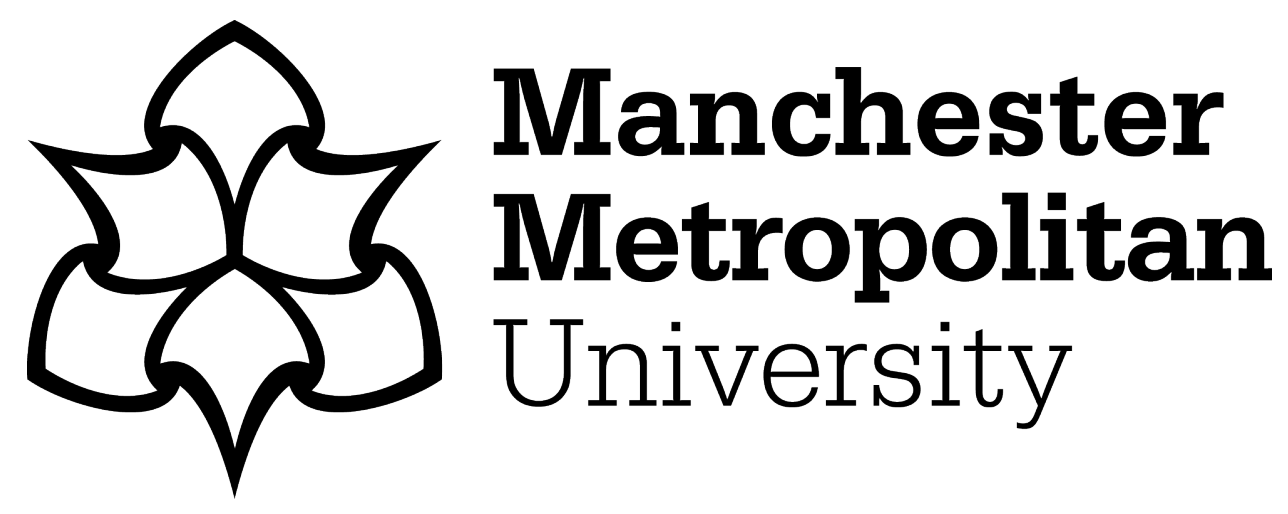

Rousell, D, Hohti, R, MacLure, M and Chalk, HL (2021) Blots on the Anthropocene: Micropolitical Interventions With Young People in a University Museum. Cultural Studies: Critical Methodologies, 21 (1). pp. 27-40. ISSN 1532-7086

Downloaded from: https://e-space.mmu.ac.uk/626558/

Version: Accepted Version

Publisher: SAGE Publications

DOI: https://doi.org/10.1177/1532708620953187

Please cite the published version 


\title{
Blots on the Anthropecene: Micropolitical interventions with young people in a university museum
}

Accepted Version: Authors' final pre-print

Cultural Studies $\leftrightarrow$ Critical Methodologies. September 2020.

doi:10.1177/1532708620953187

\author{
David Rousell, RMIT University \\ Riikka Hohti, University of Helsinki \\ Maggie MacLure, Manchester Metropolitan University \\ Hannah-Lee Chalk, Manchester Museum
}

Corresponding author: Dr David Rousell: david.rousell@rmit.edu.au 


\title{
Blots on the Anthropocene: Micropolitical interventions with young people in a university museum
}

\begin{abstract}
In this paper we discuss a series of artistic interventions in a university museum co-created by young people, researchers, and museum curators. We focus on the codevelopment of techniques for disrupting and re-imagining museological spaces and times, while exploring young people's shifting sense of inheritance in relation to the "Anthropocene" as a particular figuration of the current epoch. Drawing together an eclectic range of sources at the intersections of schizoanalysis, posthumanism, decolonial studies, and surrealism, we argue that young people's interventions in the museum constitute micropolitical nodes of resistance to the colonial-capitalistic capture of subjectivity that dominates the current epoch.
\end{abstract}

Keywords: critical museum studies; micropolitics; subjectivity; decolonisation; Guattari; posthumanism

\section{Introduction}

In this paper we discuss the development of artistic interventions in a university museum created by a group of young people called the Young Adventurers, working in collaboration with the authors and a range of museum curators. We describe the co-development of techniques for "decolonising the unconscious" (Rolnik, 2017) within the institutional spaces of the museum, building on schizonanalytic figurations of the unconscious and the machinic production of subjectivity articulated in the works of Felix Guattari $(1995 ; 2008 ; 2011)$. The paper focuses on the evolution of a creative process through which our research group began 
to create abstract inkblots and place them around the museum, a collective experiment that came to intervene in the public spaces of the museum's galleries. The process proceeded from exploring the floors and levels of the museum's public galleries, as well as selected backspaces and storages normally closed to public audiences, and culminated in the curation of an interactive artwork called the Blotwalk. The inkblots became for us a means of making space for narratives beyond the Western encyclopaedic logic of categorisation and mastery (Singh, 2018), while also marking colonial blindspots, exclusions, and dispossessions in the museum's gallery spaces and collections. Questioning museological attempts to codify and contain the unconscious within reductive determinations of the bounded, humanist subject, we describe how the inkblots came to gesture toward "a subjectivity outside-of-the-subject", resisting the colonial-capitalistic alienation of subjectivity from its living conditions and vital force (Rolnik, 2017).

The paper contributes to new materialist and posthumanist turns in critical heritage studies and museum education, which are currently reconceiving museological practice through relational and pluralistic ontologies (Harrison, 2015). Through this work, the ways in which children and young people bodily and spatially engage with museums are being reexamined (Hackett, Procter \& Kummerfeld, 2018; MacRae, Hackett, Holmes \& Jones, 2018), while museums themselves are being repositioned as critical sites of political resistance and decolonisation under conditions of climatological and socioecological crisis (Cameron \& Neilson, 2014). Museums have become fertile grounds for exploring contested figurations of the current epoch as a time typified by catastrophic climate change, mass extinction, and the commodification of life processes (Muir et al, 2015; Möllers, 2013). The last decade in particular has seen a shift towards more creative and critical interrogation of museums. As the normative histories, collections, practices and purposes of the museum have come under question (Harrison, 2012; Harrison, 2015; Cameron \& Neilson, 2014; Cameron, 2015; Janes, 
2009; Janes \& Sandell, 2019), a distinctive body of work has begun to gather around critical museum studies that actively "frame and promote posthuman theories and practices of life (Cameron, 2018, p. 349).

This paper's contribution to posthumanist museum studies focuses on questions of the unconscious and micropolitics in disrupting normative encounters in the museum with young people. In doing so, we draw together an eclectic collection of theoretical and practical engagements with the surrealist movements of the early $20^{\text {th }}$ century, the institutional critique of contemporary artist Mark Dion (2005), the art-psychiatry of Hermann Rorschach, Indigenous and decolonial theory (Todd, 2015; Yusoff, 2019), and the schizonanalytic theories of Suely Rolnik (2017) and Felix Guattari (2011). Methodologically, our project involved a Baroque approach in which we engaged experimentally with assemblages of objects, museum spaces, and concepts in an effort to elaborate "an entangled, confounded vision that resists the god's-eye perspective and the clarity of scientism” (MacLure, 2006, p. 731). In what follows, we describe how our schizoanalytic engagement with inkblots developed through spontaneous encounters in the museum, eventually developing into micropolitical interventions aimed at resisting the normative forces and overcodings that characterize the imperialist tradition of natural and cultural history museums.

The research that forms the basis of this paper emerged from the transdisciplinary Manifold Lab for Biosocial Studies of Learning and Behaviour at Manchester Metropolitan University in 2019. The focus of our collaborative project was on the question of what it feels like for young people to inherit a world typified by climatic, social and biopolitical crisis, a research initiative that we called Inheriting the Anthropocene. The project sought to engage critically with the Anthropocene as a particular conceptual, material, and affective figuration of the current epoch, focusing on how the epoch is being sensed and felt by young people, and simultaneously, how museum spaces might be differently experienced and imagined at 
the micropolitical level. Young people (ages 11-14) were invited to join the Young Adventurers research team through an open call for participation released through the Museum's network, social media, and flyers distributed across the city of Manchester. Our call was specifically phrased as an invitation for young "movers, shakers, makers, hackers, activists, and dreamers" interested in disrupting and re-imagining what a museum could be. This open-ended approach was distinctive in positioning the museum itself as a primary medium or "milieu" for young people to encounter, explore, cultivate, question, experiment, and express their emerging figurations and sensibilities of the epoch.

Over the course of this project, decolonial concerns came increasingly to the fore as we explored the complexity of young people's encounters with the museum's galleries, collections, and store rooms containing over 4.5 million objects, the vast majority of which are never seen by the public. Manchester Museum provided a rich space for this kind of critical experimentation, as a university museum comprising both "natural" and "cultural" histories along with its own contested history of colonial acquisition and display spanning nearly two centuries. As stated on Manchester Museum's website (2020), the institution was founded in 1835 by a "small group of wealthy men" who shared an interest in collecting artefacts of natural history. The museum's collections grew primarily through the donation and acquisition of privately owned artefacts by wealthy collectors, and was transferred to its current building at the University of Manchester in 1890 (see Figure 1). Over the course of the $20^{\text {th }}$ century the museum expanded its remit across both natural and cultural histories, as philanthropic funds were directed toward significant acquisitions in the areas of botany, Egyptology, entomology, ethnography, mineralogy, palaeontology, numismatics and zoology, as well as the collection of "live specimens" in the museum's aquarium and vivarium. At the time of writing, the museum is undergoing a major infrastructural renovation of both its buildings and its public face, with the ambition of "becoming more 
inclusive, imaginative, and relevant" for the diverse communities it serves (Manchester Museum, 2020).

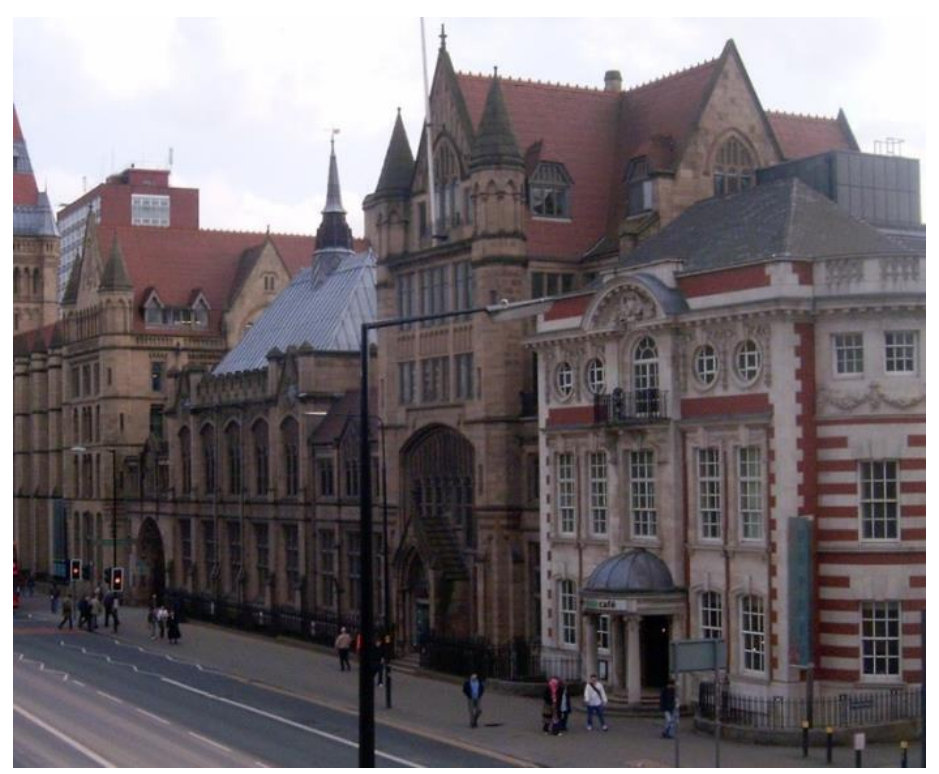

Figure 1: The Victorian facade of Manchester Museum's buildings and collections. Source: Creative Commons.

Complex questions around the decolonisation of museums became increasingly salient over the course of our project, as the Young Adventurers remained strong proponents of the idea of avoiding dogmatic, tokenistic, or clear-cut answers. They were ready to handle uncertainty and ambiguity as they critically and creatively questioned the role of museums and their politics of possession, value and care in connection with both the Anthropocene and colonialism. In many cases, young people's concerns were phrased in the shape of questions which were difficult to respond to. Our research team kept an ongoing archive of what came to be called "unanswerable" questions, such as:

"Why do museums get all the time more and more stuff?"; "Does caring for something mean keeping it?"; "Is it 'stealing' or 'taking care of' objects?"; "When something was taken from you long ago do you forget about it? How long does that take?"; "Can the museum continue to grow forever?”; “Can we keep 
everything in the end?"; "Can people care about things that they don't know they possess?"; "Is it possible to find the owners of objects that are thousands of years old?"; "Is it possible for the museum to have an example of everything?"

As these questions concerning value and politics, temporal complexities, and authenticity accumulated throughout the series of workshops, conventional museological practices of selecting, naming, organizing, classifying, arranging, keeping, caring and preserving started to feel less innocent and more problematic. This ongoing litany of questions also became the basis for a participatory artwork called the Bureau of Unanswerable Questions, which invited members of the public to rifle through the hundreds of questions asked by young people, and to add their own questions to the growing archive of "unanswerables" (see Figure 2).

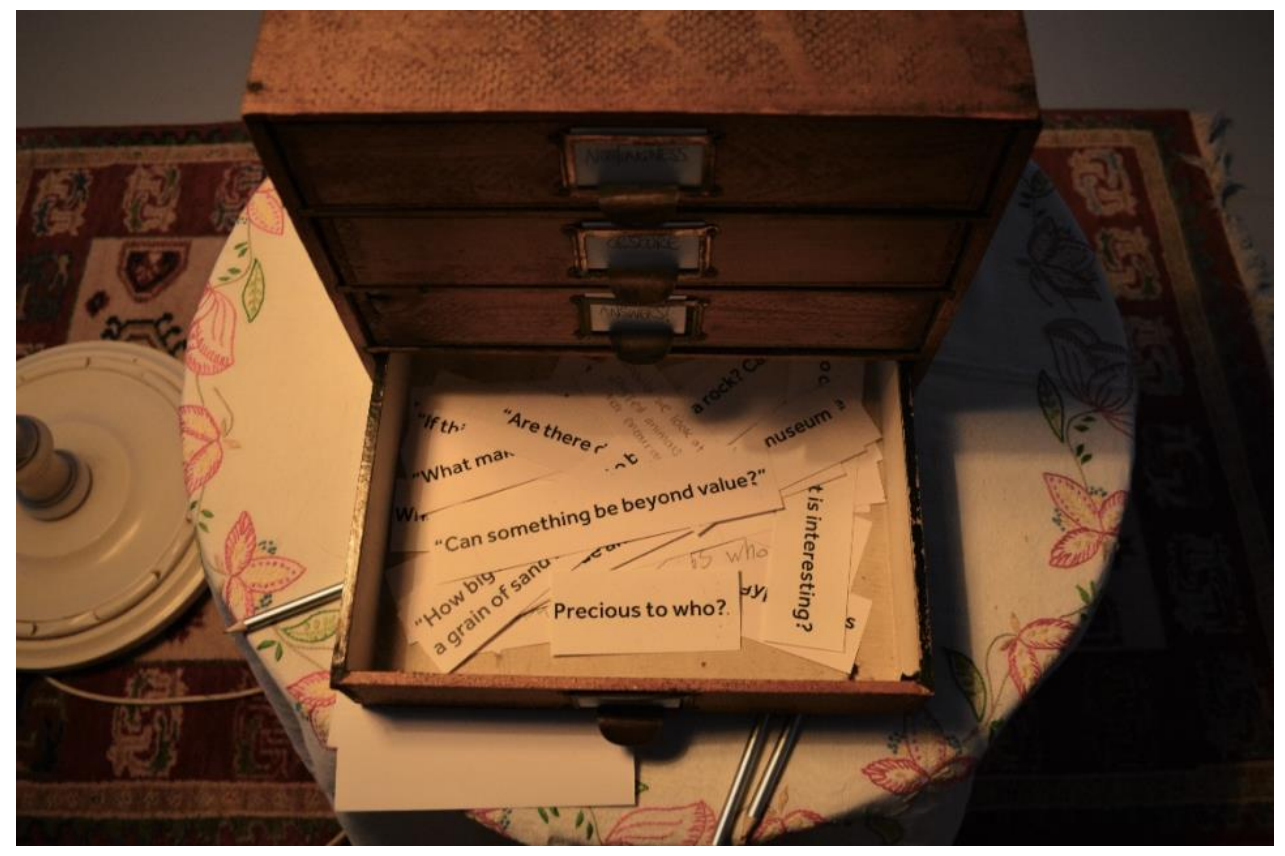

Figure 2: The Bureau of Unanswerable Questions, found museum cabinet and over one hundred unanswerable questions posed by the Young Adventurers in the museum

In another recent paper we focus on the non-innocent relations of care and curiosity that young people noticed and operationalised within the museum, recognising how the desire 
to care for particular things can serve a colonial logic of mastery and domination over natural and cultural worlds (Hohti, Rousell, \& MacLure, 2020). In this paper we are concerned more specifically with how young people questioned the way that museums can fix a particular humanist image of the subject in place and time, a subject who is the privileged experiencer, knower, master, and inheritor of scientific and cultural knowledge (Singh, 2018). We argue that this impoverished image of the unitary subject is intimately entangled with the reinforcement and conservation of what Rolnik (2017) terms the "colonial-capitalistic unconscious". We share our collaborative work with young people as a means of resisting the reduction of experience to the humanist subject in public spaces such as museums, while also establishing alternative modes of engagement and encounter with more ecological conceptions of subjectivity, politics, and unconscious labour.

\section{Anthropocene: An Epoch Without a Name}

The question of how it feels for young people to inherit the subjective and ecological degradations of the contemporary epoch haunts our concerns throughout this paper. Our argument pivots on the acknowledgement of a coextensive connection between the extractive degradation of the Earth's environmental ecologies and the perverse degradation and alienation of subjectivity from its vital force and living conditions (Rolnik, 2017). This position aligns with decolonial critiques of the Anthropocene as a universalising figuration of Western misthought (Yusoff, 2019). Recent work in decolonial studies suggests that there are inextricable links between the logics of extraction that underpin the planetary-scale genocide of Indigenous peoples, the trans-Atlantic slave trade, the mass destruction and contamination of ecological systems, and the extractive mining and burning of fossilized minerals (Karera, 2019; McKittrick, 2011; Saldhana, 2019; Todd, 2015; Tuana, 2019). Capitalism, colonialism, scientism, and racism are seen to be inextricably bound and operationalised through a logic of 
extraction, domination, and mastery, which at the level of the epoch has become a geologicscale project of planetary subjection (Demos, 2018). Yusoff (2019) argues that the geologic extraction and displacement of so-called "natural resources" such as water, mineral and oil deposits are indissociable from the extraction and displacement of living bodies as "fungible" matter ${ }^{1}$ through the historical genocide of Indigenous people and the transatlantic slave trade. From this perspective, the vision of the Anthropocene as a "new geologic age" of planetary stewardship is flawed, resting on a false image of a universal humanity that fails to recognise a brutal colonial past and its afterlives in the present.

As the Anthropocene proclaims the language of species life - anthropos- through a universalist geologic commons, it neatly erases histories of racism that were incubated through the regulatory structure of geologic relations. (Yusoff, 2019, p. 2)

As Todd (2015) further argues, the naming of the epoch as Anthropocene propagates a false image of a universal human "race" equally vulnerable and equally responsible for global environmental crisis. By foregrounding the ontological plurality of Black and Indigenous knowledge practices and socioecological histories, decolonial projects render the current epoch unnameable (Todd, 2015) and unmappable (Moten, 2018), or at least demand as many names and maps as there are modes of existence in the contemporary moment. The Anthropocene becomes an empty signifier for an unnameable epoch in which the colonialcapitalistic regime achieves planetary dominance, while attempting to erase its own (violent, barbaric) tracks with the promise of a "humanity" in common.

In this paper, we are concerned with the Anthropecene as one of many inadequate and (im)possible namings of an unevenly distributed catastrophe-event transpiring at the epochal scale, rather than as a universal marker of human impact on the Earth's natural systems. Our

\footnotetext{
${ }^{1}$ In her book Scenes of Subjection: Terror, Slavery, and Self-Making in Nineteenth-Century America (1997), Hartman uses the term "fungability" to describe the colonisation of the enslaved body as commodity with exploitable properties.
} 
interest here is less with the naming or dating of the epoch and moreso with its serialised induction, capture, and impoverishment of subjectivity in situated places and times of encounter. In other words, we are concerned with the Anthropocene as what Deleuze (1994) terms a "sense-event", in which the combined powers of aesthetic sensation, affect, and thought grapple to make some kind of "sense/non-sense" of the contemporary moment. In this respect, Manchester Museum provided a site for grappling with the inherited effects of the epoch as both traumatic and enlivening for young people, while also enabling us to challenge a museological space that has historically conserved, or "held in place", a particular (white, Western, male) image of the liberal subject. This type of subjective conservation or "conservatism" is readily apparent in conventional museological practices of (dis)possessing and exhibiting Indigenous and non-Western artefacts as neutral "displays" dissociated from any cultural, political, or ethical concerns. Through such practices, museums conserve and maintain what Todd (2015, p. 243) terms "'white public space'- space in which Indigenous ideas and experiences are appropriated, or obscured, by non-Indigenous practitioners". Some museums have become increasingly attuned and responsive to the injustice of this ongoing (dis)possession and expropriation of Indigenous cultures. As part of a current "tide of change" in response to calls for decolonisation in the museum sector, Manchester Museum has been engaged in an ongoing project of repatriation and reconciliation with First Nations and Aboriginal peoples. This includes a current partnership with AIATSIS (Australian Institute of Aboriginal and Torres Strait Islanders Studies) and traditional owners from Ganaglidda Garawa country in the Gulf of Carpenteria that has resulted in the unconditional return of 43 sacred and ceremonial objects held by the museum since the 1920s (Manchester Museum, 2020).

While the conservation of the museum as "white public space" is not commonly implemented through overt physical or discursive boundaries (museums are typically "open" 
to anyone and promote aspirations for inclusion, reconciliation, and diversity), we suggest that a colonial-capitalistic regime is maintained through thresholds of passage and intelligibility which are largely invisible, and to a significant degree, unconscious (Manning 2019). ${ }^{i}$ Throughout this paper, we remain critical of how these unconscious thresholds are induced, captured, and held in place by museums, while also affirming the invention of creative techniques capable of dislodging and reopening these thresholds toward alternative social formations. To the extent that subjectivity is understood as primarily modulated and machinically "produced" by unconscious affects and drives (Deleuze \& Guattari, 1977), then the unconscious itself can be posed as the micropolitical "battleground" on which subjective resistance to the colonial-capitalistic regime can be fought. Rolnik (2008) even suggests that it may be possible for the unconscious to actively "protest" the dominant regime, as an insurgent and uncontainable force capable of refusing, resisting, finding allies, and fighting back. We see museums as critical sights for intervening in the unconscious fabrics of social institutions, producing rifts or "schizzes" (Manning, 2020) in the normative thresholds of "white public space".

\section{Surrealist Experimentation}

In addressing the unconscious as a critical site of decolonial resistance, there is an engagement throughout this paper with historical and contemporary intersections between art and psychology as fields of inquiry that connect the unconscious affects and drives with subjective and social formations at the level of the epoch. There is a historical relationship between the psychological formulations of the unconscious in the work of Freud and Jung at the turn of the $20^{\text {th }}$ century, and the experimental abstractions and intensifications of subjectivity by way of Cubist, Dada, and Surrealist movements in the Western tradition of avant-garde art. Each of these artistic movements was concerned with the fragmentation and 
undoing of the rational subject through artistic experimentation aimed precisely at unleashing the submerged affects and drives of the unconscious.

Surrealism in particular pursued direct modes of experimentation with the unconscious forces of subjectivity at play during, and in the aftermath of, both world wars. Andre Breton's Surrealist Manifesto of 1924 offers a scathing rejection of the positivist logic taking hold of Western societies in the early $20^{\text {th }}$ Century, proposing surrealism as an antidote to the "arbitrary utility... mediocrity, hate, and dull conceit" of positivism. To this end, Breton describes surrealism as the pursuit of the "actual functioning of thought" without the bland abstractions of reason, an attempt to unleash the radical potentials of dreaming and the unconscious in reimagining and reorganising social life. The surrealists were also pioneers in disrupting the taxonomic rationality of museum and gallery spaces, and the banality of the forms of engagement that these spaces afforded. At the 1938 Exposition Internationale in Paris, Marcel Duchamp suspended sacks of coal over the heads of the visitors, and in a later exhibition in New York in 1942, hung string haphazardly across the gallery space, and invited children to play ball and hopscotch amongst the works on display. The surrealists' early museum interventions can be seen as part of a mission to release untapped affects in the interstices of categorical mastery (Singh, 2018), a project taken up in the surrealist-influenced work of Mark Dion, discussed below.

Surrealism has also contracted an ambiguous historical relationship with imperialism and colonialism. In spite of the explicitly anti-colonialist stance of many proponents, the use of primitive art and ritual objects, torn from their context and put to work to disturb the psychic composure of the European bourgeoisie, opens surrealism to accusations of orientalism and cultural appropriation (Antle, 2015). Nevertheless surrealism has also made a significant contribution to the development of decolonising thought and practice. Keeling (2019) describes how surrealism has found common ground with Afro-futurism, amongst 
other genres of the Black radical tradition that reject the normative rationalisation of the unjust and the unlivable in favour of a speculative poetics and praxis of social life in the “undercommons" (Harney \& Moten, 2013). Rosemont and Kelley (2009) also describe the proliferation and influence of surrealist artists across Africa, South America, and the Caribbean, and their continued participation in the Surrealist International collective although they note the continued invisibility of Black and Lantinx surrealists in historical accounts of the art movement. Of particular relevance to this paper, the work of Black and Latinx artists and thinkers such as Aime Cesaire (2001), M. Jacqui Alexander (2005), Alexis Pauline Gumbs (2018), and perhaps less directly, Franz Fanon (2008), can be seen to engage in varied projects of "decolonizing the unconscious". Various modes of Black or AfroSurrealism are also enjoying a contemporary popular resurgence, for instance, in the cinematic works of Spike Lee (2020), Jordan Peele (2019), and Arthur Jafa (Jafa \& Campt, 2017), amongst numerous other examples in contemporary art, literature, and cinema. As Rosemont and Kelley (p. 1) acknowledge, surrealism has historically been sustained by such "spontaneous associations" between international artists, writers, and thinkers from all walks of life over the last century, continuously refusing to formalise itself as a mass movement while defending its status as "determinately minoritary".

\section{Encountering Rorschach in the Bureau}

This diverse genealogy of surrealist experimentation exerted an ongoing influence on our work with the Young Adventures in Manchester Museum, with our weekly research sessions often taking place in the Bureau of the Centre for the Study of Surrealism and its Legacy. The Bureau is a permanent art installation created by contemporary artist Mark Dion using found objects curated and re-assembled from Manchester Museum's eclectic collections and backstores (Dion, 2005). The Bureau plays on the museum's encyclopaedic 
ambition to collect a specimen or sample of "everything" that exists in the known universe. Our work with the Young Adventures involved exploring many of the museum's rarely accessed stores, discovering drawers full of Egyptian shabtis, fragments of the Book of the Dead, a rock that bends and wobbles, a chunk of the moon, an asteroid fragment from the Big Bang, among numerous other naturalcultural "wonders".

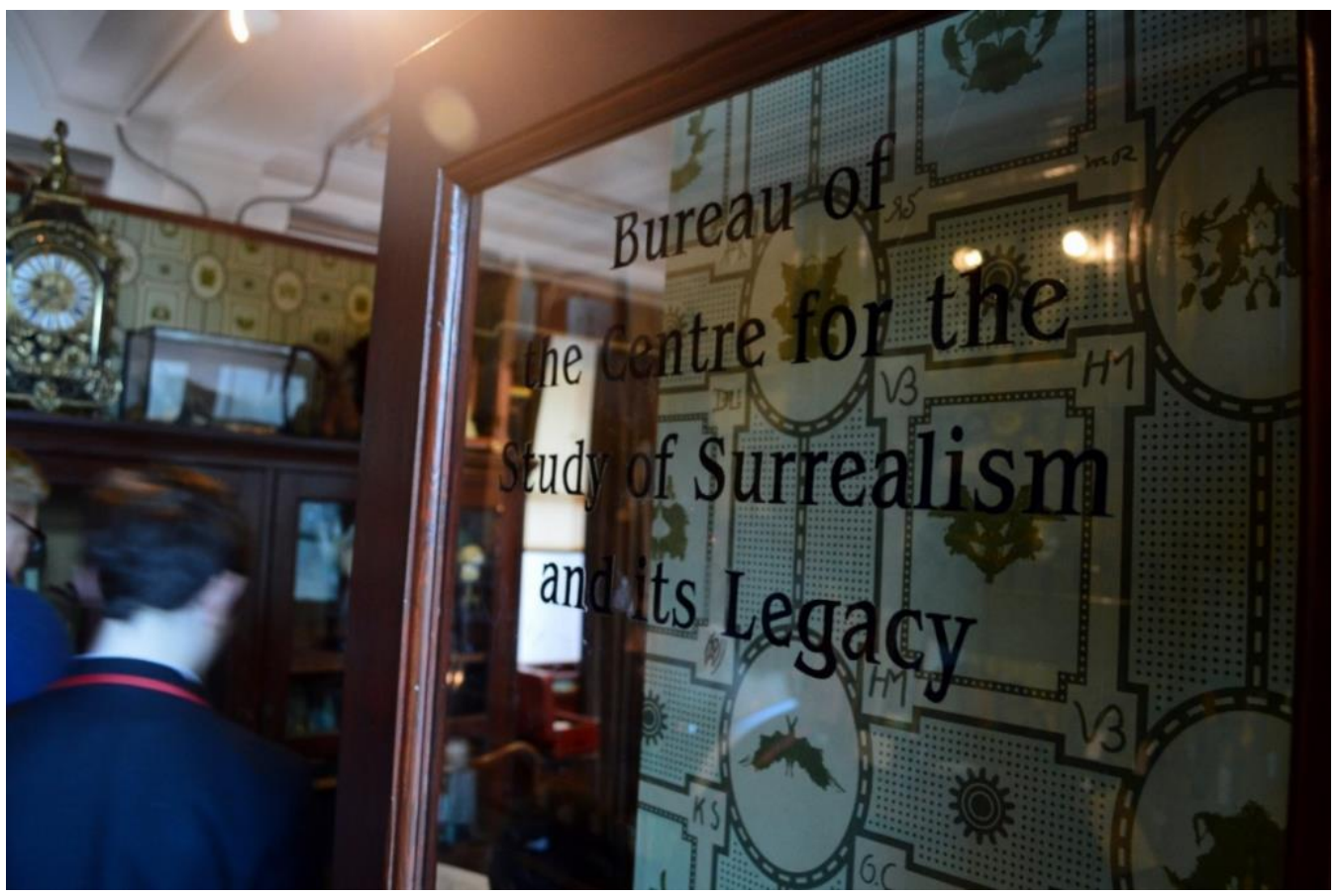

Figure 3: Entering the Bureau of the Centre for the Study of Surrealism and its Legacy.

The Museum purchased Dion's Bureau in 2005, which has since occupied a permanent space on the second floor where it is accessible to the public only by special permission (see Figure 3). The Bureau is considered a major work in Dion's oeuvre, and offers a distinctive reframing of institutional critique as a technique of socially engaged practice in contemporary art history (Endt-Jones, 2015). Rather than taking an oppositional or parasitic stance toward the institution, as many artists have done previously, Dion set out to engage directly with the museum's collections, curators, archivists, and educators to create a 
surrealist cabinet of curiosities that you can actually walk into, a gesture of actively undoing and re-imagining the history of museological knowledge, classification, hierarchies, and logics. Described by Dion as a "repository of the detritus of museum life" (Endt-Jones, 2015), the Bureau offered our research team a unique space for re-imagining the unconscious life of the museum and its objects, connecting with the historical legacy of surrealism as well as Dion's broader project of cultivating alternative modes of engagement with the more-thanhuman world (Dion et al, 1997; Erickson, 2017).

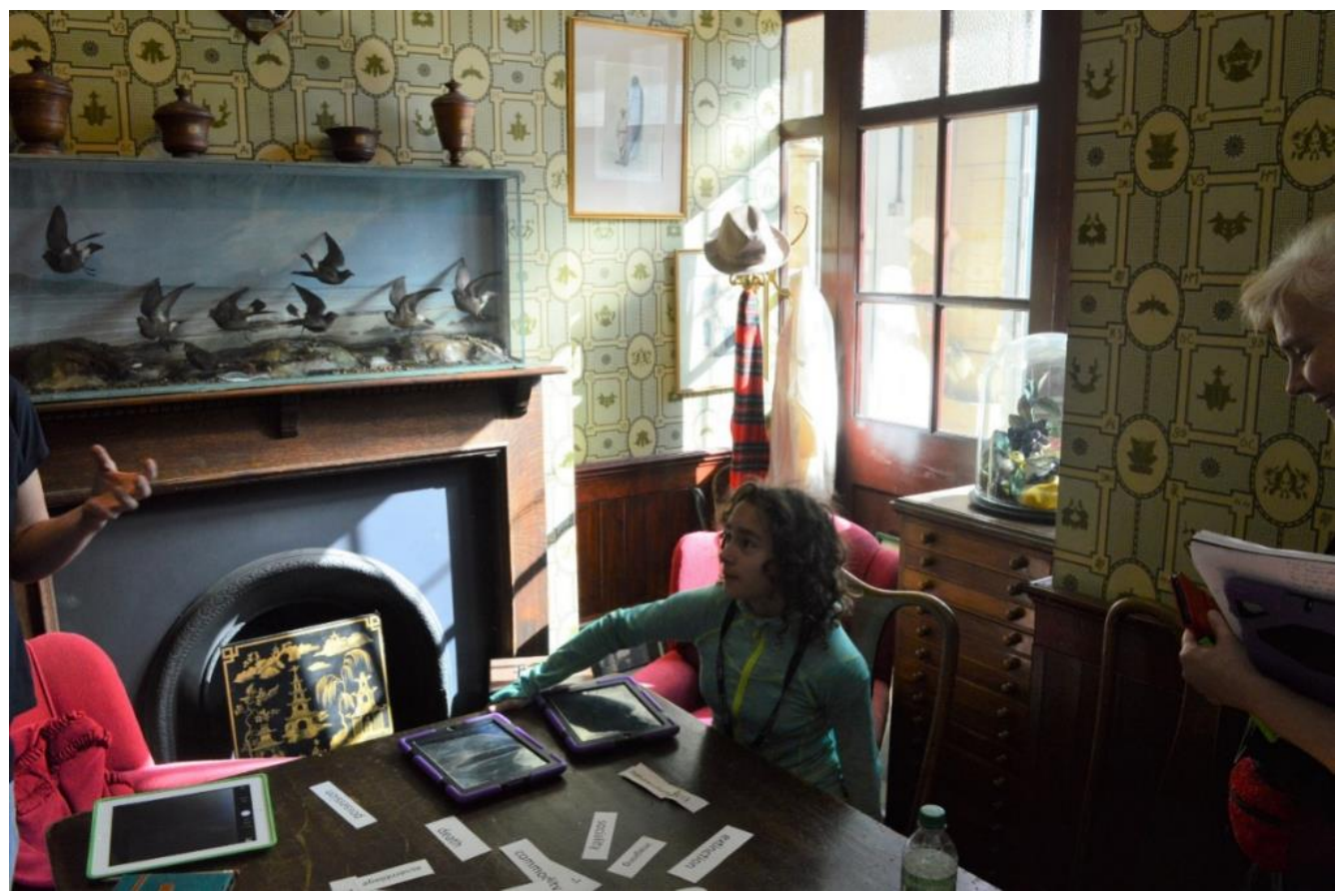

Figure 4: Working in the Bureau of the Centre for the Study of Surrealism and its Legacy.

Over a three month period, our weekly research sessions with the Young Adventurers would often begin and end in Dion's Bureau. We came to characterise the Bureau as a space for social dreaming, imagining, and thinking otherwise, for which it served both as a strangely homelike "territory" and a productive "machine" for dreaming, imagining, and experimenting in the museum (Guattari, 2011). Each week we would begin the session by selecting and discussing several concepts from a pile of cards which would grow with each session (see Figure 4). This activity helped us to think together as a pluralistic and 
intergenerational collective of adventurers, while introducing critical theoretical movements and questions into our collaborative work through concepts such as becoming, multiplicity, relation, care, potential, atmosphere, feeling, climate, colonisation, fugitivity, power, and subjectivity.

Importantly, this conceptual work entailed not so much giving definitions or making sense of the concepts, but rather a series of propositions for moving with them. For example, we played with providing instant associations (or sometimes silences) to concepts that were passed around in the group, akin to the autonomous association exercises often practiced by surrealist artists and writers. Other times we would carry selected concepts with us when moving across the storages and the exhibitions of the museum, photographing them in combination with specific objects or spaces. Sometimes we would stay in selected spots of the museum to discuss a concept chosen by one of us. In one such occasion, the concept of "climate" initiated a discussion on the affective atmospheres of the Anthropocene. To the question of how the young people felt about inheriting a planet in a state of degradation, extinction, and climatological crisis, one of the participants answered: "It's a bit like being given the Mona Lisa but with the moustache already painted on it". Referencing Marcel Duchamp's appropriation and defacing of a cheap Mona Lisa postcard in his 1919 work L.H.O.O.Q., this comment seemed to encapsulate the surreal and ironic feeling of inheriting the Anthropocene that many young people shared. This image also found its way into the Cabinet of Curiosity that the Young Adventurers assembled for our public exhibition at Manchester Museum, which featured a series of surreal assemblages of objects, images, concepts, and materials that floated in a "sea" of recycled bubble-wrap (see Figure 5). 


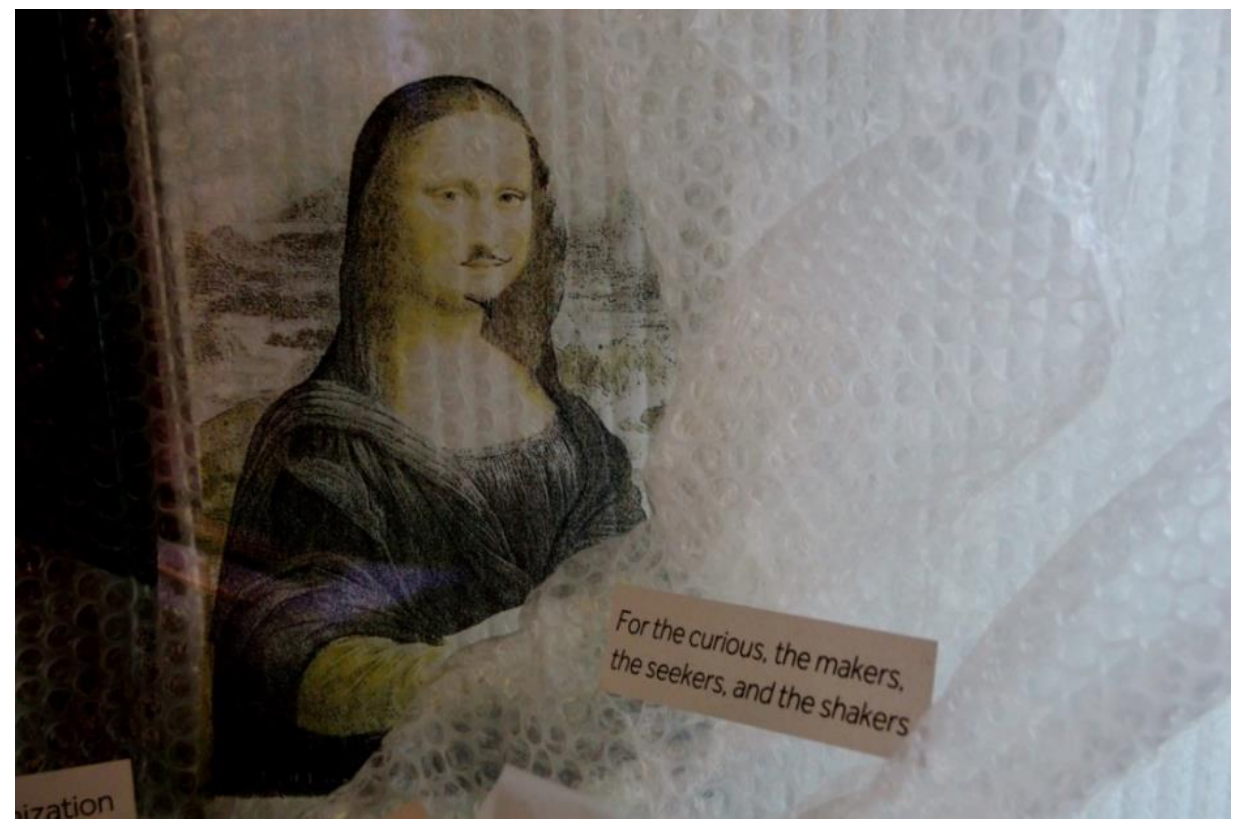

Figure 5: Detail image from the Cabinet of Curiosities, created by the Young Adventurers for the Inheriting the Anthropocene exhibition at Manchester Museum.

Leading up to the exhibition, the Young Adventurers had also begun to explore the material objects of the Bureau in more detail, using binaural recording to transform the Bureau into an instrumentarium, and discovering curiosities that were already co-inhabiting the space with us. At one point someone noticed that the taxidermy guinea pig sitting in a bell jar actually had six legs! The wallpaper in the Bureau also began to take on a sudden and irreversible significance. The wallpaper was one of the few things in the Bureau which had been created according to Dion's (2005) specifications for the work, rather than originating from the museum, and features prints of original inkblot images developed by the Swiss psychiatrist-artist Hermann Rorschach. 


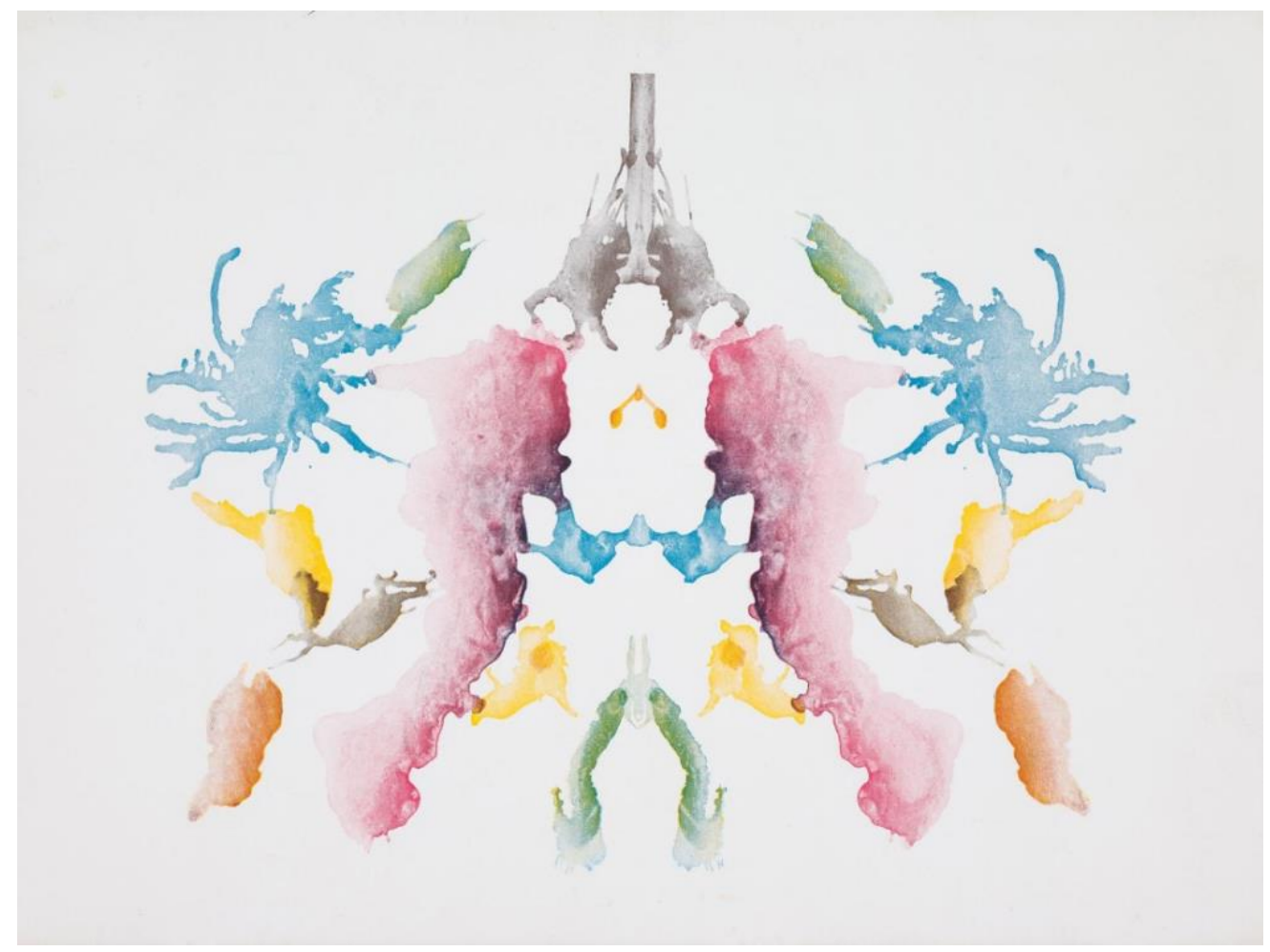

Figure 6: Original rendering of Plate 10 in the Rorschach test. Source: Creative Commons.

Rorschach created this set of 10 symmetrical inkblots in the early 1920s after studying under Carl Jung, a project that combined his life-long engagement with the visual arts and his professional practice in clinical psychiatry. The inkblots were designed to be shown to patients in clinical psychiatric sessions and used to diagnose unconscious states based on different perceptions and interpretations of symbolic form (see Figure 6). This led to an ethically complicated history of use and abuse of the inkblots as a "projective test" in the Mid-20 $0^{\text {th }}$ century, when it was used to diagnose a range of psychological states perceived to be transgressive or pathological (ranging from psychosis, to schizophrenia, to homosexuality). While it is commonly believed that particular interpretations of the inkblots are structurally linked to unconscious pathologies (for instance, linking the perception of violent imagery to violent tendencies), Rorschach's diagnostic approach was actually much more nuanced (Searles, 2017). He was less interested in the representational content or semiotic associations of what people saw in the image, and more so in the degrees of 
movement and dynamism in the perception of the blot itself. In contrast to these normative uses of the test as a means of diagnostic pathologisation, Hubbard (2019) has traced an alternative "queer history" of the Rorschach blots as tools of depathologisation when deployed by female psychologists, such as Evelyn Hooker and June Hopkins, who remain rarely acknowledged in the history of psychology. ${ }^{\text {ii }}$

In our project, the initial act of noticing the inkblot wallpaper led to an evolving engagement with the blots as tools for "diagnosing" the unconscious forces of colonialism at work in the museum, and gradually attempting to "depathologise" these colonial blindspots in creative and experimental ways. One of the young people brought our attention to the walls when she mentioned that she kept seeing different images in its abstract surfaces. This led to an extended engagement with the walls, as each of us realised that we saw completely different images in each of the inkblots. Where one person saw a bat, someone else saw a moth, a pair of elves kissing, a man with a beard, or genitalia. The inkblot wallpaper made it palpable for the Young Adventurers how only some thresholds and impressions of the museum were surfacing in our conscious minds, while other aspects that we perhaps could not perceive remained unconscious. Our further engagements with inkblots also made the movement between unconscious and conscious thresholds more explicit, as the Young Adventurers began to create their own blots and develop ideas for deploying them in the physical spaces of the museum. In this way the inkblots gradually became an agentic force capable of working "machinically" on the unconscious fabric of the museum itself, pulling at the tightly knit striations of the museum as a place of certainty, mastery, categorization, possession, and care. 


\section{Schizoanalysis and the machinic unconscious}

While the inkblots were never intended to be part of our project, their surreal emergence and attraction as "found objects" on the walls of the Bureau fit perfectly with our theoretical engagement with Guattari's "machinic" and "schizoanalytic" readings of subjectivity. While Felix Guattari is perhaps best known for his collaborative work with Gilles Deleuze (1977; 1987; 1994), his work as an (anti-) psychiatrist and activist has also been largely influential in contemporary political, cultural, and media studies, amongst numerous other fields.

Guattari's work is significant in the history of psychology because it breaks with the linguistic orientations of Freud and Jung, both of whom yoked the unconscious to underlying language structures such as the Oedipal or archetypal myths. Guattari $(1995,2011)$ theorises the unconscious as a machinic confluence of desiring-forces that constitute the production of subjectivity and the socius, breaking with the Freudian model of the unconscious as repository and theatre for historically repressed desire. As read through Guattari's machinic unconscious, Rorschach's inkblots provide a powerful example of how subjectivity operates outside of the subject as a bounded entity, such that the unconscious (both psychic and collective) is formed and reformed through the distributed play of sensuous and affective encounters with the world outside-of-the-subject.

Guattari describes the unconscious as machinic to the extent that it creatively produces and channels flows of desire and semiotic code through everyday experiences, events, and encounters in/with the world-outside-the-subject. The unconscious thus forms a compositional element in the machinic assemblages of living forces and intensities that constitute a body, an event, an interaction, a feeling, a thought, a life, a society, an institution. In contrast with a Freudian projection of Oedipal fantasies, the machinic unconscious is involved in the material labour of producing and reproducing the body and/of the socius, and indeed, participates constantly in the metaphysical labour of producing "the real" (Deleuze \& 
Guattari, 1977). From this perspective, the Rorschach blots constitute what Guattari (2011)

terms an "abstract machine" that actively produces and reproduces regimes of subjectivation and signification, rather than simply identifying and revealing underlying subjective and semiotic structures. As Guattari explains:

[The machinic unconscious] is not simply an unconscious crystallized in the past, congealed in an institutionalized discourse, but, on the contrary, an unconscious turned towards the future whose screen would be none other than the possible itself, the possible as hypersensitive to language, but also the possible hypersensitive to touch, hypersensitive to the socius, hypersensitive to the cosmos... it is populated not only with images and words, but also with all kinds of machinisms that lead it to produce and reproduce these images and words. (Guattari, 2011, p. 10)

Here Guattari offers a figuration of the unconscious as not only productive of language and representation, but also hypersensitive to the sensuous dynamics and multi-scalar complexities of relational co-existence. The projective screen of the image is no longer a Freudian theatre of repressed desire, but rather, a metaphysical surface which produces and reproduces the conditions for individual and collective subjectivities to multiply, (re)singularise, and sustain complex relations. This also makes the unconscious an ethicopolitical site of contested power relations and modulations that condition the very possibilities for what can be felt, thought, said, and done. ${ }^{\text {iii }}$

For Guattari, the figuration of a machinic unconscious demands both an ethics and a pragmatics of life-living, a rhizomatic orientation that aims to experiment and connect "all sorts of practices situated in the perspective of the changes and transformations of the existing orders and the diminishing of their power" (2011, p. 17). According to Guattari, the unconscious is primarily orientated toward the undoing of stratifications of power and territory, exerting a deterriorialising force aimed at the production of new, mutant forms of mental and social life. This micropolitical pragmatics of the machinic unconscious is what Guattari terms a "schizoanalysis" (p. 27). 


\section{Decolonising the Unconscious}

Schizoanalysis can be understood as simultaneously a pragmatics of life-living, an ethicoaesthetics of creative experimentation, and a clinical-therapeutic undoing of stratified power relations, semiotic codes, thresholds, and apparatuses of subjective capture. It is orientated primarily toward the micropolitical sphere of the unconscious affects and drives, but pursues this orientation across multiple levels and scales of existence, rhizomatically dissembling and re-assembling the life of the body through socio-political, institutional, epochal, and cosmic events. The unconscious life of the individual and the collective are therefore vulnerable to subjective capture and "machinic enslavement" by the dominant power relations of the epoch in which they come into being. Hence, from the perspective of schizoanalysis, it is the colonial-capitalistic enslavement of the unconscious which continuously produces the conditions for mass mental, social, and environmental degradation under the guise of neoliberal normativity (Guattari, 2008).

For the Brazilian psychiatrist Suely Rolnik, who collaborated for many years with Guattari, this colonisation of the unconscious is operationalised through the perverse abuse and commodification of life's vital force, a process that she terms "the pimping of life".

What distinguishes the colonial-capitalistic system is the pimping of life as a force for creation and transmutation... The vital force of the entire biosphere is expropriated and corrupted by that system: the land, the air, the water, the sky, the plants, the animals, and the human species. (Rolnik, 2017, p. 3)

Rolnik argues that the necrotic logic of extraction imposed by the colonial-capitalistic regime produces "distinct unconscious formations in the social field", formations that capture and hold bodies under the control of a colonial-capitalistic unconscious that dissociates subjectivity from its living conditions and vital force. In the Anthropocene, life is degraded and reduced to capital under a dominant regime of unconscious control and commodification, while difference is stigmatised as that which threatens to dissolve the colonial subject and its claims to mastery over self and others. This insidious double movement of colonising and 
capitalising the unconscious has effectively extended "the colonial project to its ultimate limits, its globalitarian realisation" (Rolnik, 2017, p. 1). It operates by luring, enslaving, and channelling the unconscious affects and vital drives in order to "build worlds according to the purposes of the dominant regime: the accumulation of economic, political, cultural, and narcissistic capital"' (p. 5).

For Rolnik, any movement against the colonial-capitalistic regime necessitates a process of decolonising the unconscious through techniques that dissolve the psychic grip of capitalism and colonisation at the micropolitical level. Here Rolnik makes several key distinctions between macropolitical and micropolitical modes of subjectivity and resistance. Macropolitics positions the human subject as subordinate to the power relations that order social life. In its resistant mode, macropolitics seeks to redistribute power relations in ways that are perceived to be more equitable, humane, and empowering for the subject. The sphere of the macropolitical can thus only be conceived and enacted according to a logic of the humanist subject, which recaptures any attempt at collective resistance by the very logic it seeks to oppose (p. 8). Only micropolitics, according to Rolnik (2017), is capable of resisting the capitalistic and colonial abuse of life by re-asserting the vital force of subjectivity outside of the subject, a project that aims to decolonise the unconscious by reconnecting subjectivity with the social and environmental ecologies which are its living conditions for existence and creative transmutation. Rolnik's suggestions for decolonising the unconscious focus on processes of recalibrating and revitalising the senses, affects, and drives. By activating bodily forms of knowing and embracing the fragility and vulnerability of "strange-familiar" encounters, techniques for decolonising the unconscious seek to protect the germination of embryonic worlds of subjective experience that are continually threatened and destroyed by the dominant regime of the colonial-capitalistic epoch. 


\section{The BlotWalk}

Rolnik's (2017) propositions for decolonising the unconscious became central pivot points in our work with young people in Manchester Museum, offering a matrix for grappling with the micropolitical implications of the various art interventions we were co-producing with young people. Importantly, we witnessed the decolonising and micropolitical potentials of this work emerging through and with techniques of artistic experimentation and intervention. This focus on speculative and artful practices allowed for unconscious movements and associations to develop outside of a representational logic of oppositional critique, which would have simply reinforced identitarian reductions of subjectivity to the humanist subject. Following our initial discussion about the Rorschach blots in the Bureau, the Young Adventurers began making their own inkblots in subsequent sessions, occupying a disused café space that was closed to the public while renovations in the museum were underway (Figure 7). During the process, they experimented with a variety of techniques for creating blots using different inks and papers. The process prompted repeated discussions rich with references to Dion's artwork - the Bureau and its wallpapers - and to the fact that the perceptions and meanings of the inkblots could never be fixed. Rather they were always bearing a kaleidoscope of embryonic meanings and effects that shifted from one experience to another. One of the Young Adventures suggested that the inkblots could be used to disrupt the normal flow of visitors in the museum, slowing down and provoking alternative movements, mappings, and storyings of the museum's collections as people passed through various thresholds. This idea fed into the development of our public exhibition in the museum, and eventually, crystallized into an interactive artwork called the Blotwalk. By placing the blots in oblique and questionable spaces around the museum, the Blotwalk aimed to signal Baroque possibilities for thinking the museum otherwise, while marking specific 
sites and points of colonial violence, extraction, and exclusion identified by our research collective in the museum's galleries.

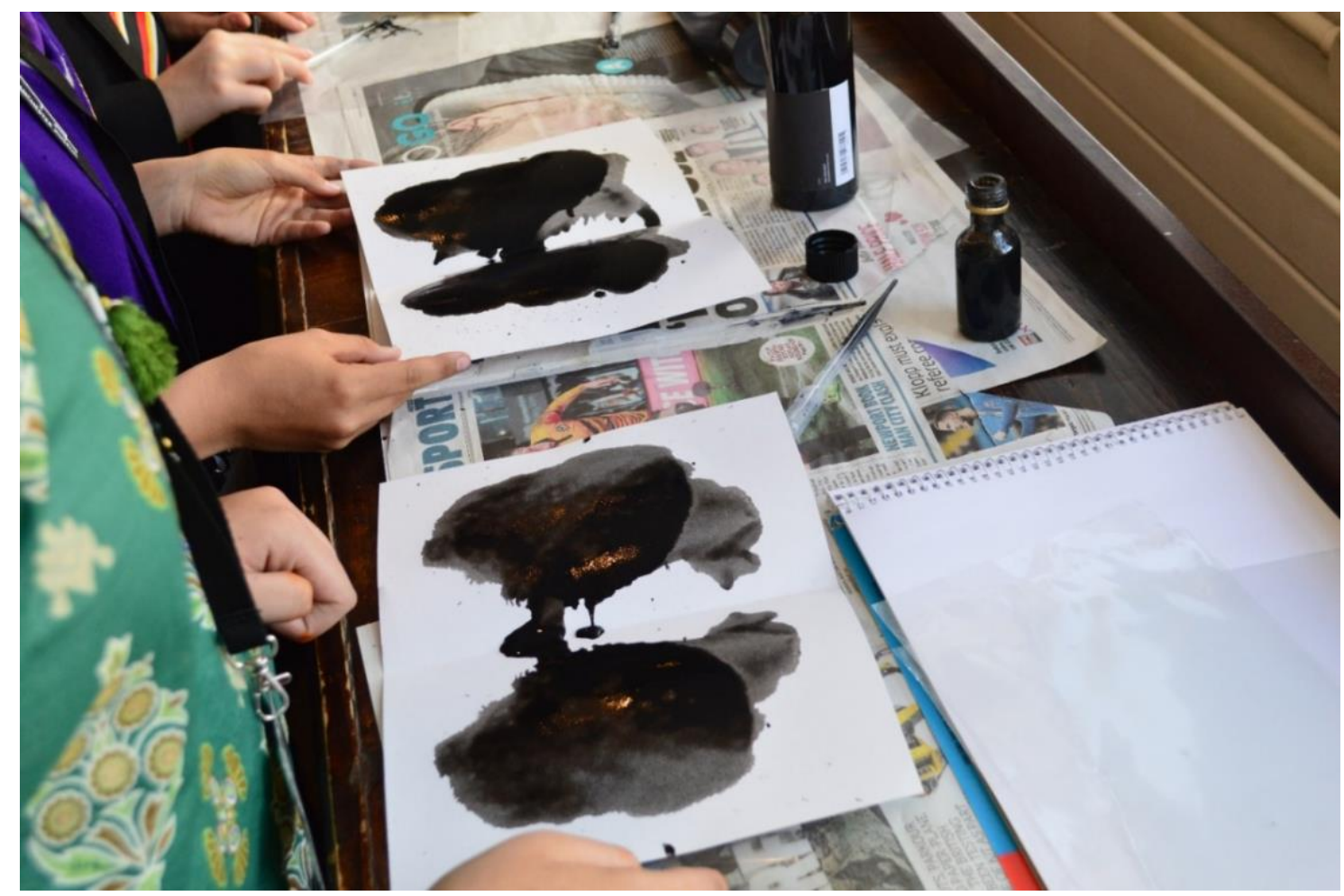

Figure 7: The Young Adventurers making inkblots in the closed café in Manchester Museum.

The Blotwalk was one of five interactive artworks installed for the Inheriting the Anthropocene exhibition in July 2019, with elements of the exhibition remaining on public display until March $20^{\text {th }} 2020 .^{\text {iv }}$ Other works in the exhibition included a Cabinet of Curiosities bringing together strange (even monstrous) assemblages of things and ideas evoking the uncertainty of young people's lives in the Anthropocene; a wearable Coat of Curiosities stuffed with everyday found objects collected by the Young Adventurers; the Bureau of Unanswerable Questions, containing hundreds of questions raised by young people in the museum; Scenes From Behind, an immersive video installation revealing parts of the museum usually restricted to the public; and Sounding Inheritance, which allowed audiences to remix the sounds of the museum recorded by young people. 


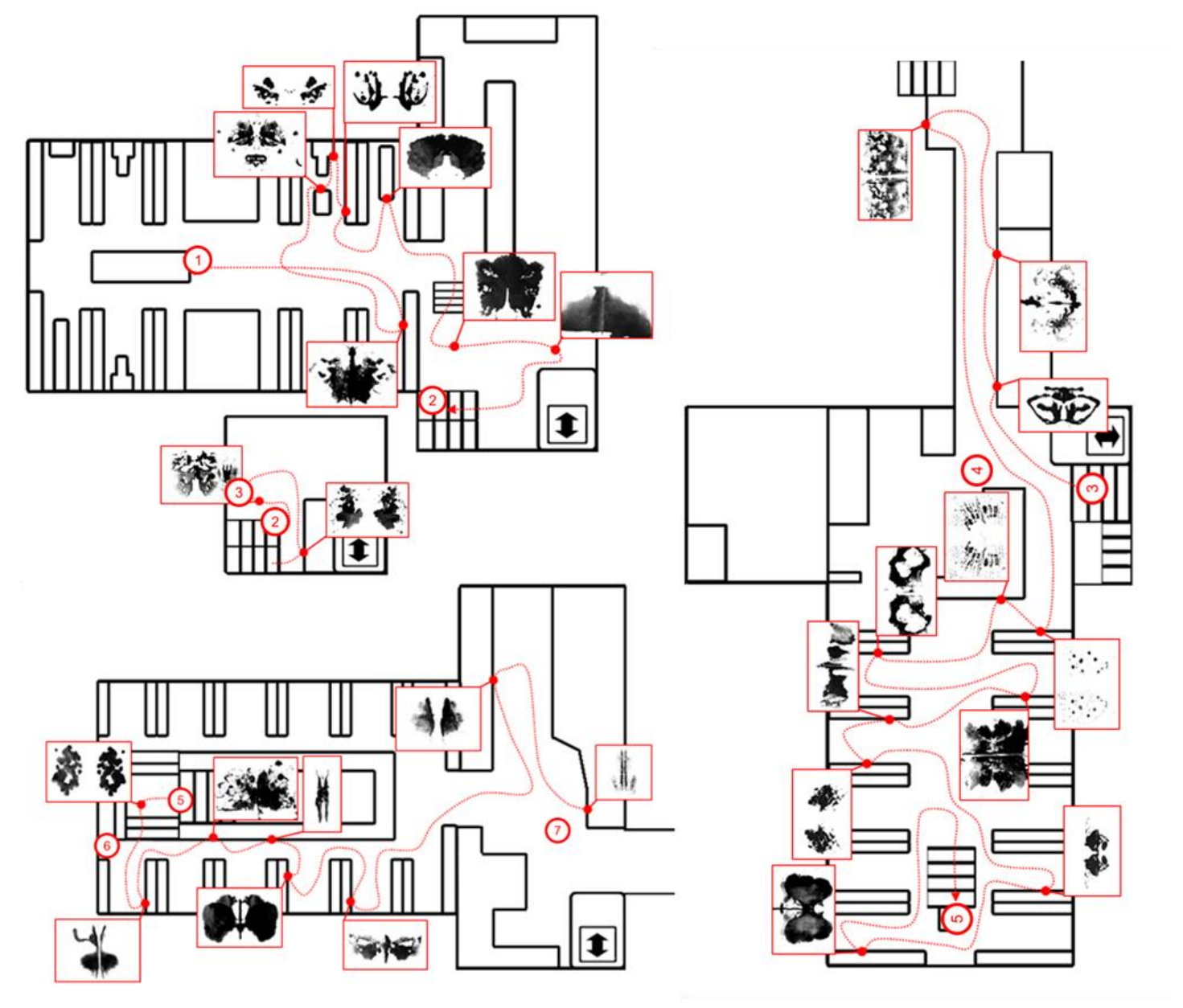

Figure 8: A composite image of the Blotwalk map showing locations of the inkblots installed by young people across three floors of the museum's galleries

The Blotwalk was the most widely distributed of these works, eventually consisting of 28 inkblots on paper which were installed at specific points across all levels of the museum's public display areas (Figure 8). We also created a map that orientated audiences to each blot within the museum, while rendering an alternative figuration of the museum as a kind of “immersive cartography” of social and subjective re-imagining (Rousell, 2020). Although Rorschach's inkblots were originally designed to diagnose unconscious pathological tendencies in the individual subject, we came to see the the Blotwalk as a technology for diagnosing the pathology of the colonial-capitalistic unconscious, while gesturing toward alternative formations of subjectivity at the micropolitical level of the social. As a 
micropolitical intervention, the Blotwalk does not operate through the emancipatory language or representational images of an oppositional macropolitics, but instead through the potentialisation of an unconscious life that both conditions and overspills the confines of signification and subjectification. As Guattari (2011) notes, this involves an engagement with the abstract (or "machinic") processes of desiring-production that both precede and condition the formation of subjectivity, semiotics, discourse, and the social as such.

The Blotwalk combined the individual blots that members of the collective each positioned independently. While there was a shared sense that the blots would actively interrupt the "normal" visitor experience of the museum and prompt people to pause and wonder, the dialogue between young people as we walked around the museum and marked locations for each blot revealed a plurality of intentions and ideas behind their chosen positioning. Some young people marked strange things, exclusions, omissions and things that felt unnerving, questionable or problematic. Others found positions for the blots that seemed to "fit" with the existing displays, with their placement marking a strange coherence or contrast of form. Others still were hidden away in nooks that would otherwise go unnoticed. Interestingly, the young people's use of the abstract inkblots to mark colonial blindspots emerged as the group confronted the volume of blots that had been produced over a number of weeks, and discussed various ways of engaging public audiences with a re-mapping and re-storying of the museum. The abstract potency of the blots seemed to exert a more powerful force than a discursive intervention aimed at the level of language and representation, which would have simply reinforced the colonial-capitalistic regime of the subject. In their fugitive abstraction from the capture of discourse and intelligibility, the blots came to gesture toward the fragile, embryonic worlds of experience that can be germinated through the micropolitical life of the unconscious and the imaginary. 


\section{Techniques of Insurgency}

In approaching the formation and enactment of the Blotwalk through the machinic unconscious and schizoanalytics, we are interested in pursuing what Guattari (2011) characterises as a pragmatics that operates through the invention and deployment of micropolitical techniques. Our focus on techniques of making and installing inkblots gestures toward a speculative pragmatics that refuses to separate the unconscious activity of the sensing body from "the practice of thinking in its full function: inextricably ethical, aesthetic, political, critical, and clinical” (Rolnik, 2017, p. 10). As theorised by Manning (2013, p. 33), techniques are inextricably physical and mental acts, and encompass an extraordinary range of human and more-than-human processes, activities, interactions, and agencies. This notion of technique is intimately linked to the sense and affectivity of bodily capacities in relation to other bodies and milieus, in a manner that acknowledges techniques well beyond the thresholds of human invention and use (Rousell, 2020).

Thinking through the Blotwalk as an assemblage of techniques, we are interested in the "minor gesture" (Manning, 2016) of action and thought that comprises an event of micropolitical rupture and intervention. Here we share several examples of how the Young Adventurers chose to install the inkblots they made in the museum (see Figure 7), which we characterise as "techniques of insurgency" operating in the micropolitical sphere. Rolnik (2017) describes such micropolitical techniques as inseparably political, aesthetic, and clinical, to the extent that they both diagnose and resist the alienation of subjectivity from the intensity of its living conditions and vital force. These techniques can be characterised as insurgent to the extent that they pre-emptively recondition the "potential possibles" (Guattari, 2011) for experience in the museum through abstract machinic processes which are diagrammatic and deterritorialising. But they can also be characterised as therapeutic, in the sense proposed by Rolnik following the relational artist Lygia Clarke, in which the work is 
orientated toward "the health of a society - that is to say, the affirmation of its inventive potential for change" (2007, emphasis in original).

In focusing on the micropolitical techniques that constitute the Blotwalk, we are attempting to think beyond the well-worn dispositifs of postmodern art, such as appropriation and juxtaposition, which would immediately raise a discursive veneer around the installation of each blot. Certainly each installation enacts a discursive cut in the presentational authority of the museum, but our focus on technique, the unconscious, the micropolitical, and the therapeutic emphasises the qualitative indeterminacy and intensity of these cuts, rather than their multiplying range of signifying interpretations. In Rolnik's terms, the blots are seen to operate through a logic of insurgent intensity, as techniques of potentialisation rather than emancipation. They are techniques that force thought to think: What is here that should not be? What is not here that could be? What other worlds of experience are silenced and excluded in order to keep this one intact? For instance, the placing of a blot over an image of the American moon landing derives from an early conversation raised by the Young Adventures about the ethics of colonising and capitalising space (see Figure 9). ${ }^{\mathrm{v}}$ Rather than mounting a discursive critique of colonial mastery and the assumption that space can be marketised, the inkblot appears more like an open wound that eats away at the very conceit of humanistic claims to achievement, recognition, and ownership. In other words, the blot opens a kind of "black hole" in the fabric of the colonial-capitalistic unconscious, suggesting that other worlds and relations of experience are both possible and necessary. 


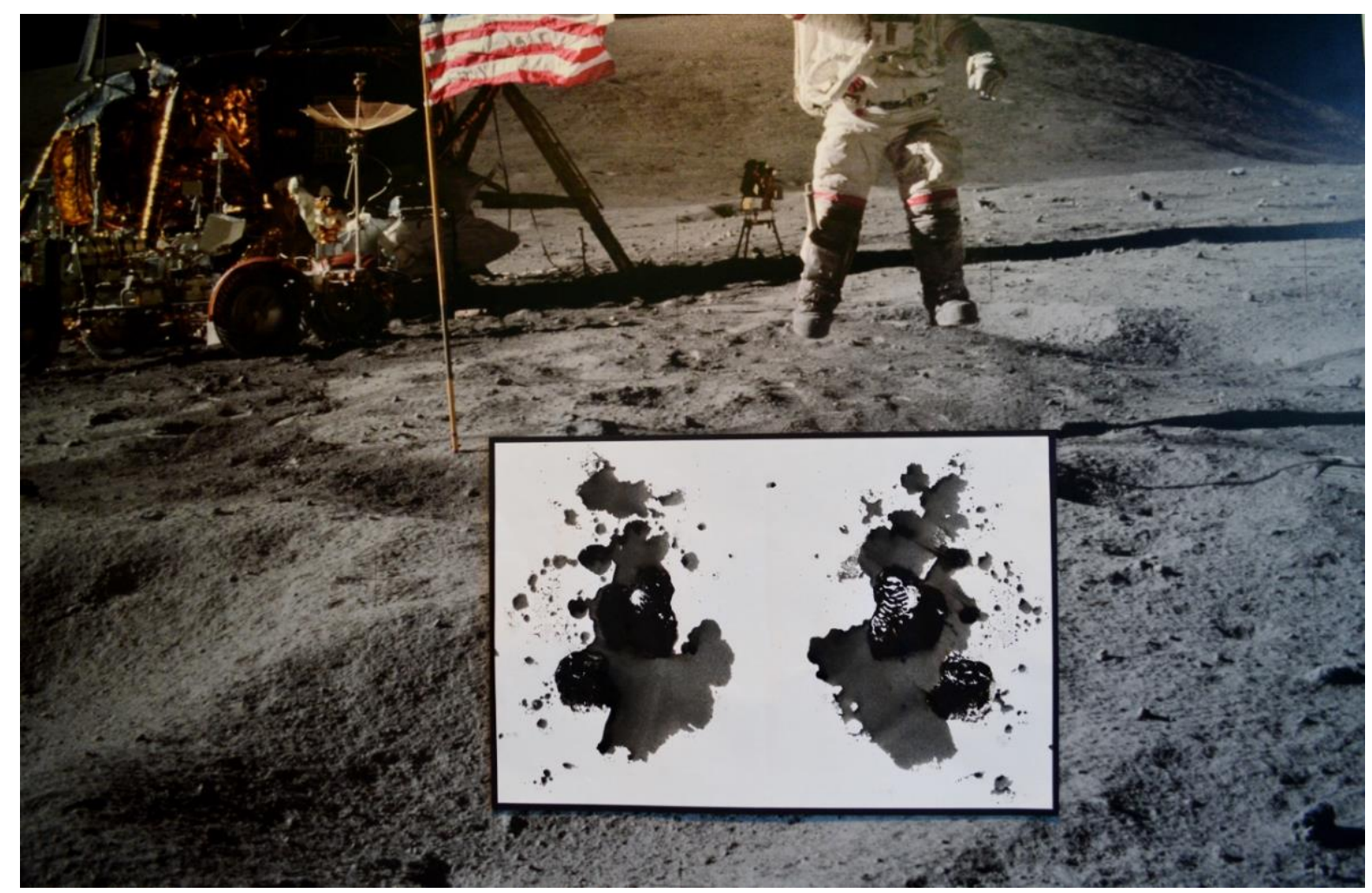

Figure 9: Inkblot installed by the Young Adventurers over an image of the American moon landing adjacent to a display of meteorite specimens.

Another blot was placed in the Living Worlds gallery on a display titled "Experience" that contains a selection of specimens alongside iconic imagery from popular culture and media. This particular display also prompts visitors to consider "how the way we feel about things has a big effect on the way we treat them, whether with respect and admiration or with fear and hatred". The blot was placed over a museum exhibit featuring a montage of images and objects assumed to invoke fear in humans, including wolves, vampires, and spiders that threaten the innocence and sovereignty of the white humanist subject (see Figure 10). The tactical placement of the blot becomes complicit with the postmodern irony of the cultural montage, and yet actively questions how cultural representations reinforce regimes of signification and subjectivity through the commodification and manipulation of aesthetic experience. 


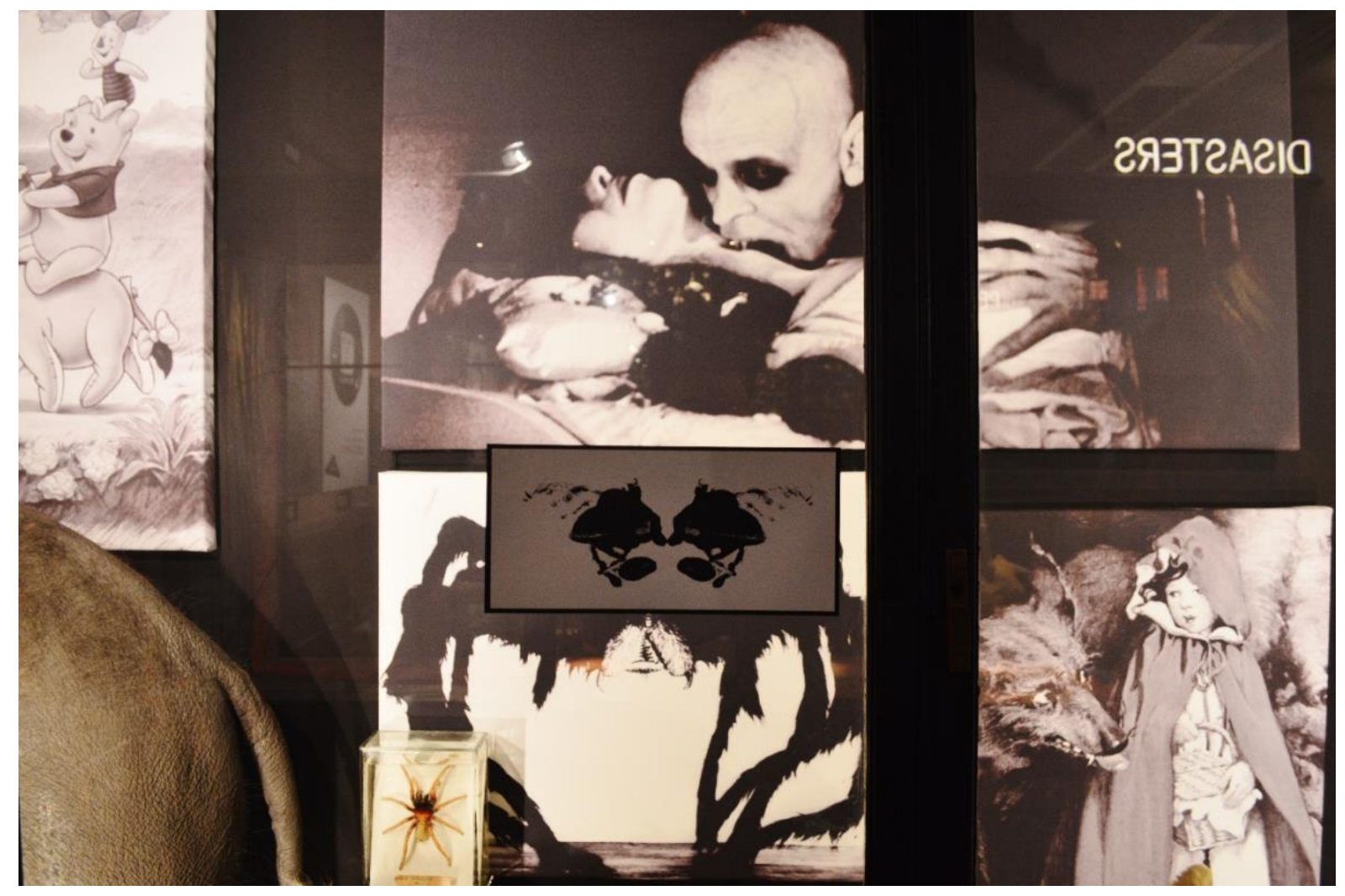

Figure 10: Inkblot installed by the Young Adventurers over the 'Experience' case in the Living Worlds Gallery of Manchester Museum

Our last example is a small blot placed over a museum display of various cotton plant matter, including fibres, threads, and silks (see Figure 11). Cotton came up many times in our ongoing discussions with the Young Adventurers due to its association with the trans-Atlantic slave trade and Manchester's industrial history as planetary-scale agents of the colonialcapitalistic regime, as well as preconditions for the current climate crisis and mass extinction agendas. Here the inkblot makes a clinical cut into the neutral presentation of historical and botanical cottons as objects of universal knowledge and scientific classification, an attempt to exhibit "things" that have somehow been purged of their associations with colonial violence so that the sovereign subject can enjoy a privileged encounter with them. The juxtaposition with silk evokes further questions regarding the colonizing relation of humans to natural worlds and other species. And yet, regardless of how a passing visitor interprets the 
placement of the Blot, it makes it nearly impossible to simply "pass" without questioning what might be missing, excluded, or buried by this display.

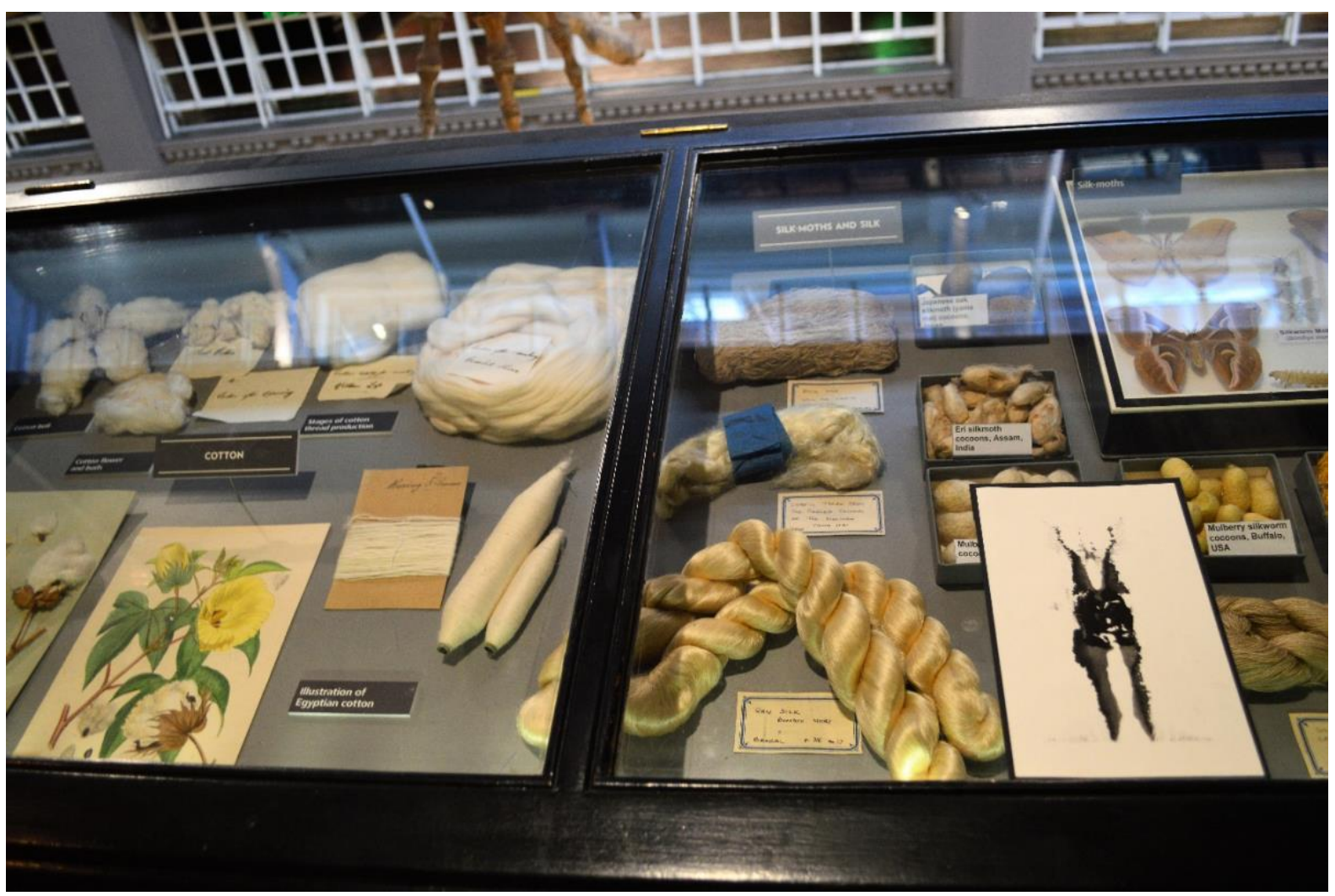

Figure 11: Inkblot installed by the Young Adventurers over a display of cotton and silk fibres in the Nature's Library Gallery of Manchester Museum

\section{Conclusion: Gestures at the Level of the Epoch}

By way of conclusion, we would like to acknowledge the small scale of our study and the gestures of insurrection that the Young Adventurers enacted within the museum. We have focused on the Blotwalk as one of several works created and exhibited during our time in the museum, while suggesting a broader strategy for resisting clarity, mastery, bureaucratic reason and the single point of view. Our broader project contributes to the emerging posthumanist and new materialist work on children's and young people's engagement with museums in which bodies, movement, museum spaces and objects are reconceptualised outside the representational paradigm of the subject (e.g. MacRae et al., 2017). However, our 
project takes a step further than many posthumanist studies in museums by working collaboratively with children and young people to create artworks that critically intervene in the museum's physical, conceptual, and affective architectures. While the impacts and resonances of these artworks are not necessarily visible, timely, or expressible through language, we argue that they are inextricably entangled with the unconscious forces and subjectivities of the epoch from which they emerge. We believe that this creative, collaborative, and activist orientation to museum-based research is necessary in order to directly challenge current figurations of the Anthropecene and its impacts on children and young people's lives. By inviting accepted theories and figurations of the Anthropecene to be contested, overturned and rerouted by young people's sensibilities and critiques of the current epoch, our activist approach to inquiry calls for the co-creation of socially transformative theories and methodologies in museum studies, posthumanism, the social sciences, and the public domain more broadly.

At one level, our study illustrates the difficulty of undoing concepts of Western humanist mastery and care by addressing the ways colonial heritage and an "anthropocenic" present are sedimented into museological architectures, materials, practices and minds. However, at the level of the micropolitical and the machinic unconscious, our project suggests that young people are highly capable of challenging the Anthropocene as a site of insurgent refusal, disjunctive imaginaries, and connective relations entangled across multiple scales and temporalities. As Rolnik (2017, p. 10) suggests, what is needed are projects that seek to decolonise the unconscious through "the infinite work of each and many", projects that are invested in "re-imagining the world in each gesture, each word, each relation, each mode of existence - whenever life requires so". Such projects are never complete, and we can never know with any precision how and where their effects will be felt, thought, and enacted. 
Yet despite this unknowability of what our work amounts to, each micropolitical gesture inevitably speaks with/against the conditions of the epoch in which it finds itself.

However localized it may be, every insurrection gestures beyond itself; it contains something global from the outset. It raises us together to the level of the epoch... The epoch must be sought deep within each situation and deep within each person. (The Invisible Committee, 2014, pp. 5-6)

Our study suggests that it is precisely by refusing to abandon difficult questions and encounters in the museum that techniques of insurgency can make the subjective thresholds and boundaries of "white public space" more palpable (Todd, 2015), and perhaps for a moment, less easy to pass through seamlessly and without question (Manning, 2019). Perhaps the Blotwalk is simply a technique for slowing things down so that the unconscious grip of the colonial-capitalistic regime can be felt, while also offering a fleeting sense of the fragile and embryonic worlds of experience that this regime forecloses. And yet, by cutting momentarily into the unconscious fabric of a public museum, such micropolitical techniques can gesture beyond themselves by asking bodies to linger in the liminal thresholds of an unmappable and unnameable epoch.

\section{References}

Alexander, M. J. (2006). Pedagogies of crossing: Meditations on feminism, sexual politics, memory, and the sacred. Durham: Duke University Press.

Antle, M. (2015). Dada and Surrealism Faced with Colonialism. South Central Review, 32(1), 116-119.

Cameron, F., \& Neilson, B. (2014). Introduction: Climate change, museum futures. In Cameron, F., \& Neilson, B. (Eds.) Climate Change and Museum Futures (pp. 1320). London, UK: Routledge.

Cameron, F. (2015). Theorising more-than-human collectives for climate change action in museums. L'internationale, 25-34. 
Cameron, F. (2018). “Posthuman museum practices” In R. Braidotti, M. Hlavajova (eds). Posthuman glossary (pp. 349-352). London: Bloomsbury Publishing.

Campt, T. M. (2017). Listening to images. Durham: Duke University Press.

Césaire, A. (2001). Notebook of a Return to the Native Land. Wesleyan University Press.

Demos, T. J. (2017). Against the Anthropocene: Visual culture and environment today. Berlin, Germany: Sternberg Press.

Deleuze, G., \& Guattari, F. (1977). Anti-Oedipus: Capitalism and schizophrenia (R. Hurley, M. Seem, and H.R. Lane Trans.). NY, NY: Penguin Books.

Deleuze, G., \& Guattari, F. (1987). A thousand plateaus: Capitalism and schizophrenia (B. Massumi, Trans.). Minneapolis: University of Minnesota Press.

Deleuze, G., \& Guattari, F. (1994). What is philosophy? (H. Tomlinson \& G. Burchell, Trans.). New York, NY: Columbia University Press.

Demos, T. J. (2018). To Save a World: Geoengineering, Conflictual Futurisms, and the Unthinkable. E-flux journal, 94.

Dion, M., Corrin, L. G., Kwon, M., \& Bryson, N. (1997). Mark Dion. Phaidon Press.

Dion, M (2005). Bureau of the Centre for the Study of Surrealism and its Legacy. London: Bookworks.

Erickson, R. (2017). Mark Dion: Misadventures of a 21st-Century Naturalist. Yale University Press.

Endt-Jones, M. (2015). Beyond institutional critique: Mark Dion's surrealist Wunderkammer at the Manchester Museum. Museum and Society, 5(1), 1-14.

Fanon, F. (2008). Black skin, white masks. Grove press.

Fleetwood, N. R. (2011). Troubling vision: Performance, visuality, and blackness. Chicago: University of Chicago Press.

Guattari, F., \& Rolnik, S. (2008). Molecular Revolutions in Brazil. South Pasadena, CA: Semiotext(e).

Guattari, F. (1995). Chaosmosis: The Ethico-Aesthetic Paradigm. Sydney, AU: Power 
Publications.

Guattari, F. (2008). The Three Ecologies. London: Continuum.

Guattari, F. (2011). The machinic unconscious: Essays on schizoanalysis. South Pasadena, CA: Semiotext(e).

Gumbs, A. P. (2018). M archive: After the end of the world. Durham: Duke University Press.

Hackett, A., Procter, L., \& Kummerfeld, R. (2018). Exploring abstract, physical, social and embodied space: Developing an approach for analysing museum spaces for young children. Children's Geographies, 16(5), 489-502.

Harney, S. \& Moten, F. (2013). The Undercommons: Fugitive planning and Black study. New York: Minor Compositions.

Harrison, R. (2012). Heritage: critical approaches. London: Routledge

Harrison, R. (2015). Beyond "natural" and "cultural" heritage: Toward an ontological politics of heritage in the age of Anthropocene. Heritage \& Society, 8(1), 24-42.

Hartman, S. (1997). Scenes of subjection: Terror, slavery, and self-making in nineteenthcentury America. New York, NY: Oxford.

Hohti, R., Rousell, D. \& MacLure, M. (2020) Atmospheric Plasticity: Non-innocent relations of curiosity, care, and curation in the museum. Paper presented at European Congress of Qualitative Inquiry, Malta.

Hubbard, K. A. (2020). Queer Ink: A blotted history toward liberation. London, UK: Routledge.

Jafa, A., \& Campt, T. (2017). Love is the Message, The Plan is Death. E-flux Journal.

Janes, R. (2009). Museums in a troubled world: Renewal, irrelevance or collapse? London: Routledge.

Janes, R., \& Sandell, R. (eds.) (2019). Museum activism. London: Routledge.

Karera, A. (2019). Blackness and the Pitfalls of Anthropocene Ethics. Critical Philosophy of 
Race, 7(1), 32-56.

Keeling, K. (2019). Queer times, Black futures. New York: NYU Press.

Lee, S. (Dir.). (2020). Da 5 Bloods [motion picture]. United States: 40 Acres and a Mule productions.

MacLure, M. (2006). The bone in the throat: Some uncertain thoughts on baroque method. International Journal of Qualitative Studies in Education, 19(6), 729-745.

MacRae, C., Hackett, A., Holmes, R., \& Jones, L. (2018). Vibrancy, repetition and movement: Posthuman theories for reconceptualising young children in museums. Children's Geographies, 16(5), 503-515.

Manning, E., \& Massumi, B. (2014). Thought in the Act: Passages in the ecology of experience. Durham, NC: Duke University Press.

Manning, E. (2013). Always more than one: Individuation's dance. Durham, NC: Duke University Press.

Manning, E. (2015). Against Method. In P. Vannini (Ed.), Non-representational methodologies: Re-envisioning research (pp. 52-71). New York: Routledge.

Manning, E. (2016). The Minor Gesture. Durham, NC: Duke University Press.

Manning, E.. (2019). How the minor moves us across thresholds, socialities, and techniques. A conversation with Erin Manning. Open! Platform for art, culture, and the public domain.

Manning, E. (2020). A pragmatics of the useless. Durham: Duke University Press.

McKittrick, K. (2011). On plantations, prisons, and a Black sense of place. Social \& Cultural Geography, 12(8), 947-963.

Mihura, J. L., Meyer, G. J., Dumitrascu, N., \& Bombel, G. (2013). The validity of individual Rorschach variables: Systematic reviews and meta-analyses of the comprehensive system. Psychological bulletin, 139(3), 548. 
Möllers, N. (2013) Cur(at)ing the Planet-How to Exhibit the Anthropocene and Why. $R C C$ Perspectives, 3(2013), 57-66.

Moten, F. (2019). The Universal Machine. Durham, NC: Duke University Press.

Muir, C., \& Robin, L. (2015). Slamming the Anthropocene: Performing Climate Change in Museums. reCollections, 10(1).

Nxumalo, F., \& Cedillo, S. (2017). Decolonizing place in early childhood studies: Thinking with Indigenous onto-epistemologies and Black feminist geographies. Global Studies of Childhood, 7 (2), 99-112.

Pappenheimer, W. (2008). Tuning in Rorschach Maps. In: Adams R., Gibson S., Arisona S.M. (eds) Transdisciplinary Digital Art, Sound, Vision and the New Screen: Communications in Computer and Information Science (Vol 7). Springer, Berlin. Peele, J (Dir.). (2019). Us [motion picture]. United States: Monkey Paw Productions. Rankine, C. (2014). Citizen: an American lyric. Graywolf Press.

Rolnik, S. (1999). Molding a contemporary soul: The empty-full of Lygia Clark. The Experimental Exercise of Freedom.

Rolnik, S. (2007). The Body's Contagious Memory: Lygia Clark’s Return to the Museum. EIPCP. European Institute for Progressive Cultural Politics, retrieved 12 January, 2020 from $\underline{w w w . e i p c p . n e t / t r a n s v e r s a l / 0507 / r o l n i k / e n}$.

Rolnik, S. (2008). Forward. In Guattari, F., \& Rolnik, S. Molecular Revolutions in Brazil. South Pasadena, CA: Semiotext(e).

Rolnik, S. (2017). The spheres of insurrection: Suggestions for combatting the pimping of life. E-Flux, 86, 1-11.

Rosemont, F., \& Kelley, R. D (2009). Introduction: Invisible Surrealists. In Rosemont, F., \& Kelley, R. D. (Eds.). Black, brown, \& beige: Surrealist writings from Africa and the diaspora (pp. 1-20). Austin: University of Texas Press. 
Rousell, D. (2020). A Map You Can Walk Into: Immersive Cartography and the Speculative Potentials of Data. Qualitative Inquiry.

Saldanha, A. (2019). A date with destiny: Racial capitalism and the beginnings of the Anthropocene. Environment and Planning D: Society and Space, 0263775819871964.

Searles, D. (2017). The Inkblots: Hermann Rorschach, his iconic test, and the power of seeing. London, UK: Crown Publishing.

Sharpe, C. (2016). In the wake: On blackness and being. Durham: Duke University Press.

Singh, J. (2018). Unthinking mastery: Dehumanism and decolonial entanglements. Durham,

NC: Duke University Press.

Steffen, W., Broadgate, W., Deutsch, L., Gaffney, O., \& Ludwig, C. (2015). The trajectory of the Anthropocene: The great acceleration. The Anthropocene Review, 2(1), 81-98.

The Invisible Committee. (2014). To Our Friends. Cambridge: MIT Press.

Todd, Z. (2015). Indigenizing the Anthropocene. In H. Davis and E. Turpin (eds). Art in the Anthropocene: Encounters among aesthetics, politics, environments and epistemologies (pp. 241-254). London: Open Humanities Press.

Tuana, N. (2019). Climate Apartheid: The Forgetting of Race in the Anthropocene. Critical Philosophy of Race, 7(1), 1-31.

Yusoff, K. (2019). A billion Black anthropocenes or none. Minneapolis: University of Minnesota Press.

\footnotetext{
' Manning (2019) draws on the work of scholars in Black studies (Hartman, 1997; Sharpe, 2015) and critical Black aesthetics (Campt, 2017; Fleetwood, 2011; Rankine, 2014) to discuss the paradoxical invisibility and hypervisibility of Black and neurodiverse bodies in public spaces. She emphasises the unconscious agency of thresholds as both visible and invisible barriers that enable and disable bodies to "pass" more or less fluidly. She notes that bodies passing as white or neurotypical never have to think about the privilege of "easy thresholding" and crossings between barriers without the burden and demand of "hyper in/visibility".
} 
ii The Rorschach inkblots have also been the subject of critical debates regarding their contested scientific validity as a method of projective testing in the human sciences. While a longitudinal study claimed that the blots were pseudoscientific in 2003 and called for a moratorium on the test (Searles, 2017), more recent systematic meta-analyses have offered counter-evidence of the blots as scientifically sound clinical instruments (Mihura et al, 2013) Rorschach's inkblots are now rarely used in clinical practice but have become quotidian images situated at the nexus of art and psychology in contemporary popular culture. And despite their ambiguous empirical and clinical veracity, evidence rendered from the inkblots remains admissible in courts and reimbursed under health insurance claims around the world (Searles, 2017), making them enduring artefactual images in the contemporary modulation and figuration of the unconscious and its agential powers.

iii In this respect, the machinic unconscious is not bound to the physical constraints of a universal space-time, occupying instead a trans-spatial and trans-temporal "plane of consistency" which continuously establishes new subjective coordinates of existence (Guattari, 2011, p. 11). Such coordinates are not the product of universal underlying structures or transcendent order, but rather the destratification and resingularisation of situated power formations across multiple constellations of space and time. This gives the machinic unconscious an "abstract" and "molecular" character, to the extent that it precedes the bifurcation of experience into subjects and objects, and sustains a molecular consistency which does not separate a machinic assemblage from its components, or from the virtual field of potentials which is its living condition.

iv A selection of material from the Inheriting the Anthropocene project is also currently being assembled to create a new display in Manchester Museum in late 2020-early 2021.

$\checkmark$ Our conversation with young people around the moon landing coincided with the first private launch by SpaceX to the international space station, proudly announced as the first commercial marketization of space through many mainstream news outlets. Since the project ended the Manchester Museum has removed the image of the moon landing from its walls. 